\title{
Earliest issues of CMAJ now
}

\section{available online}

$\mathrm{T}$ housands of hard-to-find back issues of CMAJ and other journals, including one dating to I865, are now available online thanks to the 4-year-old digitization project at PubMed Central (PMC), the giant online resource at the US National Library of Medicine (NLM).

The project (www.pubmedcentral. nih.gov/fprender.fcgi) means that hundreds of copies of CMAJ, including every issue published between the journal's launch in January IgII and September 1940 , are already available, as are issues from 1944 to I950, I979 to I98I and I984 to I998. Scanning to put the remaining issues into portable document format (PDF) is on-

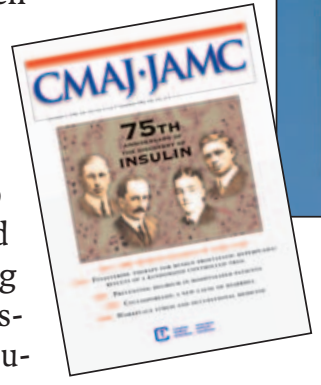
going, but will not be required for $C M A J$ issues published since I999, the year the journal's full text was made available online (www.cmaj.ca).

The cost is being borne by the NLM, the Wellcome Trust and the UK Joint Information Systems Committee. Digitization is available only to the 299 journals that deposit their material under open-access agreements with PMC, the online database of full-text biomedical and life-science literature.

The site attracted 3.I million unique users in November 2006 alone, when I2.5 million abstracts, full-text articles and PDFs were retrieved. PubMed Central's production team leader, Carol Myers, said more than 905000 articles are now available at PubMed Central, including 548 ooo scanned articles.

"The CMA was one of the first publishers to sign on as a PMC participant," she says. "The original agreement for digitization was signed in 2003 and the first batches of [scanned] material began to come in from our contractor in 2004."

She said the scanning is an "ongoing and open-ended project." The oldest scanned journal is the Transactions of the American Ophthalmological Society, first published in 1865 , followed by the Journal of Anatomy and Physiology

(now the Journal of Anatomy) in I867; $C M A J$ (IgII) shares the rank of sixth oldest scanned journal with the Bulletin of the Medical Library Association.

Myers said about 30000 of the original I82 ooo pages received from publishers remain to be scanned. "We hope to have the archive completed in the next couple of months."

CMAJ Editor-in-Chief Paul Hébert thinks the online availability of early volumes of CMAJ and other journals will encourage

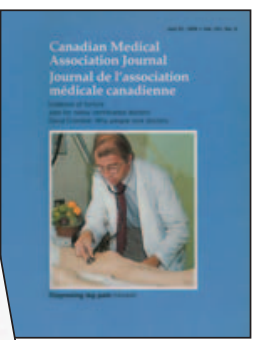
physicians to discover more about medicine's past.

"I just read one of our editorials from IgII that stated: 'The Journal is not a great sheet which comes down from heaven: it is an instrument of the profession to be used by all in the interests of all.' I couldn't have said it better myself." Patrick Sullivan, Richmond, Ont.

DOI:Io.I503/cmaj.070403

\section{More calls for ethical}

\section{investing}

Published at www.cmaj.ca on Mar. 23, 2007.

$\mathrm{T}$ The Saskatchewan Medical Association (SMA) is calling on the CMA's investment arm, MD Management Ltd., to create an ethical funds portfolio so physicians do not have to invest in companies involved in the arms trade. CMA Holdings, which includes I4 subsidiaries, has $\$ 24$ billion in assets under its administration, and IIo ooo physician and family member clients.

In May 2006, the SMA passed a resolution sponsored by Physicians for Global Survival that called upon MD Management to create a portfolio "to allow investment in a manner consistent with respect to militarism and environmental sustainability."

In a follow-up letter to Dr. Louise Cloutier, chair of CMA's board of directors, the president of Physicians for
Global Survival (Canada) asked the board for its response.

"Our understanding was that the CMA was responsible to act upon motions put forward by individual provincial medical associations," says Dr. Dale Dewar, Physicians for Global Survival's president.

In her written response to Dewar on Feb. 28, 2007, Cloutier described the issue as "challenging" for MD Management. Although the company has conducted "extensive client market research, MD has not seen any material level of demand for restrictions on investments beyond tobacco, nor has there been sufficient demand for MD to produce and bring to market an ethical fund," she states.

The SMA received a similar letter from the CMA, says SMA Communications Director Marcus Davies. Last November, the SMA reported back to its members. "What they seemed to find satisfying in the response is that MD does provide access to the ethical funds offered by other fund managers," Davies says. The issue will likely progress if physicians call their MD representatives and ask them to shift their investments to some of those other products, he suggested. "You can create demand by using them," Davies adds.

Tim Hague, vice-president of marketing for MD Management, added in an interview that MD has also received letters from clients suggesting that imposing investment prohibitions beyond the long-standing one against tobacco is an imposition of some people's views on others. He repeated MD's position that it has not seen significant demand for the company to offer its own ethical funds.

"We have never seen any material level of demand nationally, and we don't do our research by provincial association," says Hague.

But Dewar, a family physician in Wynyard, Sask., says the SMA resolution should indicate a substantial level of demand for such funds, as does the 6oo-plus membership of the Physicians for Global Survival.

She referred to The Lancet and $B M F$ s recent calls for Reed Elsevier, The Lancet's owner, to stop hosting arms fairs (see page 1265). Her organization 
and members who passed the Saskatchewan resolution would like MD to divest itself of any investments in military arms or equipment, she says.

"Military equipment has only one purpose, and that's to kill," says Dewar. "That is hardly consistent with the goals of an organization that's devoted to health."

That kind of investment prohibition is increasingly difficult because of corporate consolidation, says Hague. "The General Electric Corporation makes jet engines for both commercial and military uses. Does that mean we would not invest in General Electric? Not withstanding that they also manufacture medical and diagnostic imaging equipment? My point is that you get into a realm that becomes impossible to manage."

Physicians who want to invest in ethical funds can do so through MD's Consolidated Account, using thirdparty funds, he stresses.

Physicians for Global Survival will now urge individual members of their organization and, more broadly, the CMA, to ensure their investments are in ethical funds, Dewar says.

"Our next step is going to be on the individual level, to make sure MD Management knows of those of us who have actually taken our money elsewhere," she says. - Laura Eggertson, Ottawa.

DOI:I0.I503/cmaj.0704I8

\section{The envelope please:}

\section{Gairdner winners}

$\mathrm{F}$ ive world-class biomedical scientists are this year's Gairdner International recipients. The winners, which were announced on Apr. I8, will each receive $\$ 30000$, a certificate and a La Couer statue in Toronto on Oct. 25.

Founded in 1959 by Toronto businessman James Gairdner, the awards recognize and reward the achievements of medical researchers whose work contributes significantly to improving the quality of human life. Since their inception, the Gairdner Foundation has given 289 awards to distinguished scientists from I3 countries; 68 Gairdner winners have become Nobel Laureates (www.gairdner.org).

The work of these 5 "truly outstanding scientists reflects the importance of basic discoveries that lead to a better understanding of human disease and the development of effective treatment," said the Gairdner Foundation President Dr. John Dirks. The winners were chosen through a rigorous, 2-part, arms-length process. They are:

- Prof. David Allis, head of the Laboratory of Chromatin Biology at Rockefeller University, New York, and Kim A. Nasmyth, Whitley chair, Department of Biochemistry at Oxford University. They "are honoured for their brilliant advances in understanding genetic replication and cell division and how it can go wrong, leading to errors in human development and in making us susceptible to cancer," said Dirks.

- Dr. Dennis J. Slamon, executive vicechair for research and professor, Department of Medicine at the University of California, Los Angeles School of Medicine, who "almost singlehandedly discovered an overactive oncogene in one-third of women with breast cancer, developed the antibody directed at abnormal growth, and designed the necessary clinical trials" that resulted in the development of the targeted therapy trastuzumab (Herceptin), said Dirks.

- Harry F. Noller, director, Center for Molecular Biology of RNA at the University of California, Santa Cruz, California, and Thomas A. Steitz, Department of Molecular Biophysics and Biochemistry and the Howard Hughes Medical Institute at Yale University, New Haven, Connecticut, who "contributed to our understanding of the translation of genetic information at the level where proteins are made and where antibiotic action can be targeted," Dirks said.

The Foundation also sponsors a nation-wide program in October, including lectures at 18 academic centres and culminating in a 2-day "Minds that Matter" symposium at the University of Toronto, at which all 5 winners will speak. - Barbara Sibbald, CMAJ

DOI:IO.I503/cmaj.07045I

\section{News@ a glance}

Internet drug sales down: Canadian Internet pharmacy sales to the United States plummeted nearly $50 \%$ in 2006 , compared with 2005 , reports IMS Health Canada, which provides market information on the pharmaceutical and health care industries. In 2005, sales to the US were $\$ 420$ million; in 2006 they were \$2II million. IMS Senior Industry Expert, Ian Therriault, says the change is due to a higher exchange rate, the new US Medicare prescription plan and negative media coverage about counterfeit and foreign drugs.

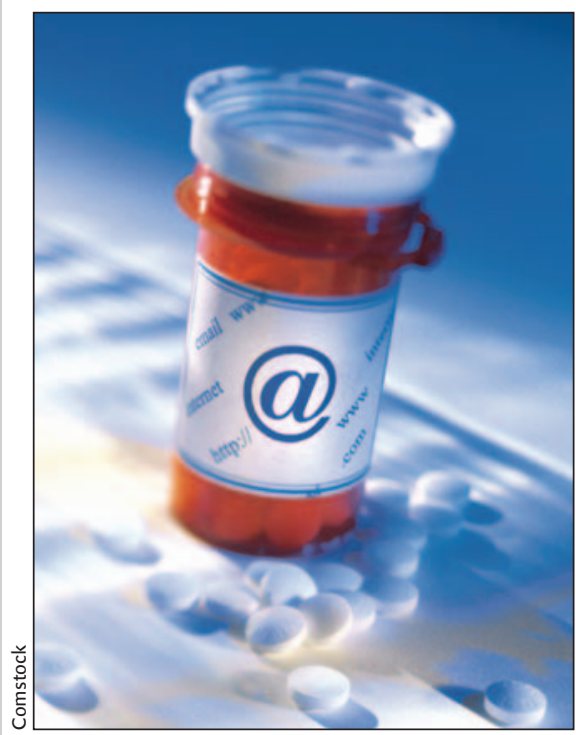

TB levels off: The global tuberculosis epidemic has levelled off for the first time since the WHO declared TB a public health emergency in 1993 . The Mar. 22 Global Tuberculosis Control Report stated that almost $60 \%$ of TB cases are now detected, and of those, the vast majority are cured. Over the past decade, 26 million patients have been treated for TB. However, the disease still kills 4400 people daily or an estimated I.6 million in 2005. An addition US\$I.I billion is needed to meet the 2007 funding requirements set by the Global Plan to Stop TB (2006-I5). In related news, the World Medical Association is piloting a new online TB course to help physicians better diagnose, prevent and treat multidrug-resistant TB (www.wma.net). Compiled by Barbara Sibbald, CMAJ 